Agro-Science Journal of Tropical Agriculture, Food, Environment and Extension Volume 19 Number 3 (July 2020) pp. 40 - 44

ISSN 1119-7455

\title{
AN ASSESSMENT OF THE IMPACT OF HUMAN ACTIVITIES ON WILD BIRDS AND FISHES IN DAGONA WATERFOWL SANCTUARY, NIGERIA
}

\author{
${ }^{*}$ Saleh A. and ${ }^{2}$ Ahmed A. \\ ${ }^{1}$ Department of Geography, Federal University, Gashua, Nigeria \\ ${ }^{2}$ School of Preliminary Studies, Sule Lamido University, Kafin Hausa, Nigeria \\ *Corresponding author's email: abbasalehgs@gmail.com, abubakar8550483@gmail.com
}

\begin{abstract}
Natural resources management and conservation has been a persistent theme in discourse of human survival and environmental development. Conservation means the sustainable use and protection of natural resources. It is also seen as the process through which natural resources are managed to allow partial or total exploitation for individual, community, or commercial use without jeopardizing the long-term ability of the resource base for future generations with minimal environmental damages. The study employed systematic sampling techniques in selecting the respondents for the interview. The selection was based on the settlement arrangement in the study site as sampling frame. The structured questionnaires were administered to the respondents with aid of research assistant for proper interpretation of the questionnaire to local language (Bade). The study found that there were different bird species both native and migratory birds from Europe and other parts of the world. The use of these birds includes tourism, source of meat, income and beautification of the natural environment. Farming hunting and fishing remain the dominant economic activities that provide income, food and tourism in the area. Hunting and fishing reduces the number as well as the composition of birds and fish species in the area. Protopterrus annectens and Egretta garzetta were the dominant fish and bird species respectively. A lot of efforts were made to conserve and protect the waterfowl against natural and anthropogenic effects from national and international environmental concern organizations.
\end{abstract}

Key words: natural resource, human activities impact, wild birds, fishes, Dagona Waterfowl Sanctuary

\section{INTRODUCTION}

Naturally, the survival of any organism on earth depends on exploitation of resource in the environment (Aliyu, 1993). It is the environment that provides man with resources that are utilized in several sectors, ranging from agriculture to manufacturing industries. Ezealor (2002), regarded environment as the sum of all external conditions affecting the life, development and survival of an organism. On the other hand, the exploitation and processing of these environmental or natural resources is referred to as human activities (Akanji et al., 2016).

The Dagona Waterfowl Sanctuary is a functional ecosystem endowed with a variety of resources that are of socioeconomic and ecological importance to the people (Crump, 1991). According to Manu (2000), a sanctuary is any area of land or sea specially dedicated to the protection of biological diversity. And of natural and associated cultural resources, and is managed through legal or other effective means. It is also for economic value, domestication and biotechnology potentials (Auwalu, 2004). The establishment of the waterfowl sanctuary in Dagona stems from the threats to the environment due to the demand for resources by increasing human and animal population whose survival depends solely on resources exploitation
(Idowu et al., 2020). It was this concern for scarce resources that resulted in the formation of the Natural Resources Conservation Council under Decree No 36 of 1991 with the Head of State as the Chairman (Auwalu, 2004).

It is important to note that the survey of the sanctuary was first conducted in 1949 and this was followed by the establishment of a 300-date palm tree plantation in 1963 (Rowley and Winter, 1998). The then Borno Native Authority designated the area a Site of Special Conservation Interest (SSCI) in 1966 (Mbanyiman, 1990; Wakirwa, 1999). Later, the area was declared a sanctuary on $17^{\text {th }}$ Feb., 1987.

The ultimate goal of establishing Dagona Waterfowl Sanctuary is to improve the general quality of life of the people and sustainable utilization of the resources therein. The success of any policy establishing a conserved or protected area depends largely on proper utilization and effective management by both the people and the concerned authorities, especially, the fact that all protected areas are social spaces (Adewumi, 1998; Gisilambe, 1998). The conservation of the sanctuary is for resources protection and maintenance for future prosperity (IUCN, 1988). The study examined the contemporary status, diversity and composition of fish and bird species in the sanctuary. 


\section{MATERIALS AND METHODS \\ The Study Area}

Dagona Waterfowl Sanctuary is part of the BadeNguruwet lands sector in Yobe state, Nigeria. The sector is found between latitudes $12^{\circ} 13^{\prime}-13^{\circ} 00^{\prime} \mathrm{N}$ and longitude $10^{\circ} 00^{\prime}-11^{\circ} 00^{\prime} \mathrm{E}$. It covers an area of $9385 \mathrm{~km}^{2}$. The Dagona Waterfowl Sanctuary being the focal point of the sector made Dagona village the most important of all the villages in the Bade Local Government Area (Auwalu, 2004).

The Dagona Waterfowl Sanctuary is one of the three major ecological entities designated as fully protected areas under the control of Chad Basin National Park (Stopfords, 1999). It serves as a habitat for waterfowl. The area is a Fadama (a valley-bottom, floodplain or lowland around a river that floods or becomes wet when the river is high) which is flooded in the wet season; it is endowed with diverse physical and biotic composition (Ipinyolu, 1999). The area is situated in a semi-arid environment (Manu, 2000). The climate therefore is hot and dry for most part of the year. Temperature rises up to $43^{\circ} \mathrm{C}$ in the hottest months of May to June, the dry season lasts from November to June, the rainy season starts in early July and ends in October (Manu, 2000). Rainfall is generally erratic in its distribution and amount; it roughly lasts for 120 days. Rainfall values range from 23 to $335 \mathrm{~mm}$, while the mean annual rainfall is about $180 \mathrm{~mm}$. (Auwalu, 2004). The vegetation is entirely Sahel savannah type which consist of mainly drought resistant tree species (xerophytes) such as Doum palm (Hypenia thebaica), African Mahogany (Khaya Senegalis), Acacia species such as Gum Arabic (Acacia nilotica) Senegal gum (Acacia Senegal) Neem (Azadiricta indica) among others. Fishing, farming and hunting are the major economic activities in the area (IUCN, 1988).

\section{Sampling Technique}

Systematic sampling technique was used to cover Dagona through which heads of households were selected as samples and interviewed as respondents. Their selection was based on their house arrangement which was used as sampling frame for this research work. Houses were skipped houses at regular interval of two houses before conducting an interview exercise with another respondent. The interview exercise was conducted with each head of household selected. The questionnaire was divided into three sections $\mathrm{A}, \mathrm{B}$ and $\mathrm{C}$ where section $\mathrm{A}$ contained questions on the respondents' personal profile while section B contained questions on environmental impact of the sanctuary, resources, ranking and their uses and section $\mathrm{C}$ contained questions or items on socio-economic impacts of the sanctuary. The method of the questionnaire administration employed was self-administered method in which the researcher met the respondents in their respective places of resident to interview them. The choice of this method of questionnaire administration was largely due to the fact that quite a substantial number of the respondents were not literate enough to answer the questions on their own. The researcher sought the assistance of three research assistants who were literate and also fluent in the dominant local language of the Bade tribe.

\section{Statistical Analysis}

The percentage method of statistical analysis was adopted. In rating the effectiveness of the conservation measures in the sanctuary, a list of conservation measures were listed as options for the respondents to select the one that best suit their interest or opinion and out of these options or alternative conservation measures, the one that was chosen by the highest percentage of the people was then regarded as the most effective conservation measure in the sanctuary.

\section{RESULTS AND DISCUSSION \\ Socio-Demographic Characteristics of the Respondents}

Table 1 shows some of the socio-demographic characteristics of the respondents. People below the age of 18 constitute only $3.1 \%$ which is a very insignificant percentage of the respondents. People in the age group 57-69 years represent $15.62 \%$. Overall, the age group 44 and above represents over $70 \%$ of the respondents. The active age group comprises people who are aged 18-42 years. They represent the youths, who are to be innovative and up-to-date with regard to conservation and environmental consciousness.

\section{Educational Qualification of the Respondents}

Education being the basis for any meaningful development also serves as a weapon against poverty, hunger, ignorance and diseases. It can also be seen from Table 1 that, out of the respondents, only $3.13 \%$ were educated up to a degree level. The form of education with the highest percentage is Quranic Education with 41.25\%.

\section{Occupation of the Respondents}

The occupation of the respondents before and after the establishment of the sanctuary indicated little differences in the percentages for the occupations, as can be seen from the data in Table 1. Before the establishment of the sanctuary, only $12.19 \%$ of the respondents were in civil service and trading but presently or after the establishment of the sanctuary the percentage of the respondents who are engaged in the civil services or trading has increased up to $31.25 \%$. This shows that there has been a palpable occupational change among the people due to the establishment of the sanctuary in the area. More people engaged in farming, fishing and hunting to improve their livelihood. 
Table 1: Socio-demographic characteristics of the respondents of the study

\begin{tabular}{|c|c|c|c|c|}
\hline Age Group & \multicolumn{2}{|c|}{$\begin{array}{l}\text { Number of } \\
\text { respondents }\end{array}$} & \multicolumn{2}{|c|}{ Percentage (\%) } \\
\hline Less than 18 & \multicolumn{2}{|l|}{10} & \multicolumn{2}{|l|}{3.1} \\
\hline $18-30$ & \multicolumn{2}{|l|}{26} & \multicolumn{2}{|l|}{8.1} \\
\hline $31-43$ & \multicolumn{2}{|l|}{40} & \multicolumn{2}{|l|}{12.5} \\
\hline $44-56$ & \multicolumn{2}{|l|}{43} & \multicolumn{2}{|l|}{13.43} \\
\hline $57-69$ & \multicolumn{2}{|l|}{50} & \multicolumn{2}{|l|}{15.62} \\
\hline $70-82$ & \multicolumn{2}{|l|}{84} & \multicolumn{2}{|l|}{26.25} \\
\hline 83 and above & \multicolumn{2}{|l|}{67} & \multicolumn{2}{|l|}{21} \\
\hline Total & \multicolumn{2}{|l|}{320} & \multicolumn{2}{|l|}{100} \\
\hline Qualification & \multicolumn{2}{|c|}{$\begin{array}{l}\text { Number of } \\
\text { respondents }\end{array}$} & \multicolumn{2}{|c|}{ Percentage (\%) } \\
\hline Degree or its equivalent & \multicolumn{2}{|l|}{10} & \multicolumn{2}{|l|}{3.13} \\
\hline Diploma or its equivalent & \multicolumn{2}{|l|}{21} & \multicolumn{2}{|l|}{6.56} \\
\hline SSCE or its equivalent & \multicolumn{2}{|l|}{42} & \multicolumn{2}{|l|}{13.13} \\
\hline Primary school & \multicolumn{2}{|l|}{79} & \multicolumn{2}{|l|}{24.25} \\
\hline Quranic education & \multicolumn{2}{|l|}{132} & \multicolumn{2}{|l|}{41.25} \\
\hline Others & \multicolumn{2}{|l|}{36} & \multicolumn{2}{|l|}{11.25} \\
\hline Total & \multicolumn{2}{|l|}{320} & \multicolumn{2}{|l|}{100} \\
\hline Occupations & $\begin{array}{l}\text { Numbe } \\
\text { respon }\end{array}$ & $\begin{array}{l}\text { of } \\
\text { ents }\end{array}$ & Percen & ge (\%) \\
\hline & Before & After & Before & After \\
\hline Crop production & 160 & 106 & 50 & 33.12 \\
\hline Animal rearing & 56 & 53 & 17.5 & 16.57 \\
\hline Fishing & 24 & 22 & 7.2 & 6.88 \\
\hline Hunting & 41 & 39 & 12.81 & 12.18 \\
\hline Others (civil service $\&$ teachi & ng) 39 & 100 & 12.19 & 31.25 \\
\hline Total & 320 & 320 & 100 & 100 \\
\hline
\end{tabular}

Wild Birds in the Sanctuary, Their Uses and Ranking (Section B of the Questionnaire)

Table 2 shows the major types of wild birds found in the sanctuary, how the respondents use them, and their ranking before and after establishing the sanctuary. As can be seen in this table, the bird Plagedis Fakinellus (Sarauniyar Kyau [Hausa]) maintained its ranking as number one bird before and after the establishment of the sanctuary, Anas sparsa used to be number two bird before the establishment of the sanctuary but as at the time of this research it was ranked third, while Egretta garzetta maintained number seventeen before and after the establishment of the sanctuary. The uses of these birds according to the respondents include tourism, income generation (through hunting of the wild birds) beatification and as a source of meat. The sanctuary is blessed with local and migratory birds that visit the area from Europe (Ringim et al., 2017). People regard these birds as readily available source of food and income. However, both the local and migratory birds are found to be fast decreasing due to poaching and unregulated hunting. Birds are hunted for meat, caught for domestication or displayed in cages for sale (Weins, 1997). The Hadejia-Nguru Wetlands Conservation Project (HNWCP), Royal Society for the Protection of Birds (RSPB), Nigerian Conservation Foundation (NCF) and Chad Basin National Park (CBNP) are organizations that initiated measures and put many resources in place order to protect the birds from poachers and hunters. The people however, regard the measures as an attempt to deny them their right. They accuse the authorities for giving much consideration to birds instead of their situation as humans, because of that hunters do not find the conservation measures as being important and beneficial to them. For any policy to succeed people as stakeholders in any development should be accorded priority. There is much to be done to protect the remaining threatened birds in the sanctuary. Most of the structures put in place in the sanctuary require serious attention, like many other projects, the sanctuary is also rot by insufficient funding.

Table 2: Wild birds in the sanctuary, their uses and ranking

\begin{tabular}{|c|c|c|c|c|c|}
\hline $\mathrm{S} / \mathrm{N}$ & Scientific Names & Hausa Name & Uses & Ranking & \\
\hline & & & & Before & After \\
\hline 1 & Plectropterus gambensis & Dinya & M, I, T, B & 03 & 02 \\
\hline 2 & Leptoptilos crumeniterus & Borin-tinke & $\mathrm{M}, \mathrm{T}$ & 08 & 07 \\
\hline 3 & Anas clypeata & Tinjimi & $\mathrm{M}, \mathrm{T}$ & 06 & 08 \\
\hline 4 & Balearica pavonina & Gauraka & $\mathrm{M}, \mathrm{T}, \mathrm{B}$ & 07 & 06 \\
\hline 5 & Anas querquedula & Kwasakwasa & $\mathrm{M}, \mathrm{T}$ & 09 & 10 \\
\hline 6 & Serkidionus melanota & Kwarwa & $\mathrm{M}, \mathrm{T}, \mathrm{B}$ & 11 & 09 \\
\hline 7 & Sagittarus sepentarias & Kakakiya & $\mathrm{M}, \mathrm{T}, \mathrm{B}$ & 12 & 11 \\
\hline 8 & Francitinus bicakaratus & Fakara & $\mathrm{M}, \mathrm{T}$ & 04 & 05 \\
\hline 9 & Numida meleagris & Zubuwa & M, I, T, B & 05 & 04 \\
\hline 10 & Anas sparsa & Kwakwa & M, I, T, B & 02 & 03 \\
\hline 11 & Plagedis falcinellus & Sarauniyarkyau & $\mathrm{M}, \mathrm{T}$ & 01 & 01 \\
\hline 12 & Phoenicopterus minor & Zalbe & $\mathrm{T}$ & 16 & 16 \\
\hline 13 & Egretta garzetta & Balbela & $\mathrm{T}$ & 17 & 17 \\
\hline 14 & Circaetus galhaus & Shaho & $\mathrm{T}$ & 15 & 15 \\
\hline 15 & Falcon tinnunculus & Kabarai & $\mathrm{M}, \mathrm{T}, \mathrm{B}$ & 14 & 13 \\
\hline 16 & Limosa limosa & Buru-Buru & $\mathrm{M}, \mathrm{T}, \mathrm{B}$ & 10 & 12 \\
\hline 17 & U. senegalensis & Kahuhu & $\mathrm{M}, \mathrm{T}, \mathrm{B}$ & 13 & 14 \\
\hline
\end{tabular}

Source: Field Work, 2018. Key: M - Meat, T - Tourism, I - Income, B - Beautification 
Table 3: Fishes in the sanctuary, their uses and ranking

\begin{tabular}{llllll}
\hline S/N & Scientific Names & Hausa Name & Uses & \multicolumn{2}{c}{ Ranking } \\
& & & Before & After \\
\hline 1 & Oreochsomis niloticus & Karfasa & M, I, T & 01 & 01 \\
2 & Clasias anguillaris & Tarwada & M, I, T & 02 & 02 \\
3 & Lates niloticus & Musko & M, I, T & 04 & 03 \\
4 & Alestes macrolepidotus & M, I, T & 05 & 04 \\
5 & Bagrus bayad & Ragon-ruwa & M, I, T & 08 & 09 \\
6 & Schilbe mystus & karaya & M, I, T & 06 & 05 \\
7 & Hydrocymus forskalli & Tsage & M, I, T & 15 & 14 \\
8 & Synodontis nigrita & Kurungu & M, I, T & 10 & 10 \\
9 & Heterotis niloticus & Margi & M, I, T & 07 & 06 \\
10 & Polypterus senegalus & Gartsa & M, I, T & 09 & 07 \\
11 & Malapterurus electrucus & minjirya & M, I, T & 12 & 15 \\
12 & Gymnarcus niliticus & Dan-sarki & M, I, T & 13 & 03 \\
13 & Hetero branchusbidorsalis & Jari & M, I, T & 11 & 11 \\
14 & Protopterrus annectens & Gaiwa & M, I, T & 14 & 12 \\
15 & Momyrus rume & Sawayya & &
\end{tabular}

Source: Field Work, 2018. Key: M - Meat, T - Tourism, I - Income

\section{Fishes and Their Uses}

Table 3 illustrates the species of fishes existing in the sanctuary and their usefulness to the respondents. The uses to which these fishes are put by the respondents include tourism, source of income and source of meat for human consumption. The names are given in both scientific and Hausa. The ranking of these fishes before and after the establishment of the sanctuary shows very insignificant changes as many of these fishes retained their ranks before and after the establishment. Fishing is one of the major human activities in the area and this is largely due to the presence of rivers and streams which makes water available for production of fish for domestic consumption and commercial use as a source of income.

Fishing, being one of the predominant activities in the Dagona village takes place during dry season, but it is occasionally done during the rainy season. Initially fishing activity was not properly regulated in the area and this caused so much damage to the fisheries resources of the sanctuary (Ramsar Convention Bureau, 2000). Because of its importance to the socioeconomic life of the people, government and non-government organizations, amongst which are North East Arid Zone Development Program (NEAZDP), Hadejia-Nguru Wetlands Conservation Project (HNWCP) and Yobe State Ministry of Livestock and Fisheries initiated a number of conservation measures through policy formulation on fishing gears, development of artificial fish ponds, strict law on harvesting and consumption of young fish. The major constraint to the measures put in place is the people's attitude; they have to exploit the fisheries resources in order to survive. But fishing regulations for rational exploitation of resources are feasible, taking into consideration the need to sustain humanity. Despite the importance of the fisheries resources to human survival, the need to create awareness about the dangers of over fishing among fishermen cannot be overemphasized. Therefore, fishermen are advised to seek viable alternative(s) to diversify their livelihood.

\section{CONCLUSION}

Dagona people are engaged in exploitation of natural resources through various human activities such as fishing and hunting for livelihood. The study concludes the composition and diversity of both fish and bird species have reduced by $20 \%$ and $28.44 \%$ respectively. These human activities have obvious negative impact on the sanctuary and they do not guarantee sustainable utilization of the natural resources (birds and fishes) as time goes on. Although many governmental and non-governmental organizations are involved in the conservation activities in the sanctuary to save the environmental resources for the benefits of man.

\section{RECOMMENDATIONS}

People's Partaking in Policy Formation/Execution Any conservation policy formulated should be people oriented so as to carry people along. The people are the beneficiaries, they are in a better position to contribute and appropriate the conservation activities. Such policy must reflect their social, economic and cultural status.

\section{Environmental Education}

Sustained campaign about the risk of unsustainable utilization of the resources through various human activities. The people at the rural level should be educated on how to protect, utilize and maintain the quality and quantity of the environmental resources without jeopardizing their livelihoods.

\section{Funding}

The Dagona Waterfowl Sanctuary management and other relevant ministries and organizations should be given enough money that would be judiciously used to facilitate their smooth operation.

\section{Acquisition of Skills}

The people should be encouraged, through capacity building to acquire technical skills that will enable them partake in decision making and implementation as well as management of the sanctuary. 


\section{REFERENCES}

Adewumi, B.A. (1998) Developing indigenous machinery base for crop and food processing industry in Nigeria. Proc. National Engineering Conf. Nigerian Society of Engineers, held in, Maiduguri, Nigeria, pp. 3-49

Akanji A.M., Fasina O.E., Ogungbesan A.M. and Adeleke G.A. (2016). Laying performance, haematology and serum biochemical profile of hens fed unfermented and fermented African locust beans. Agro-Science, 15 (1), $1-5$

Aliyu A. (1993), Editorial in Park News the Newsletter of Kanji Lake National Park, Vol. 2

Auwalu A. (2004). An Assessment of People's Attitude towards Conservation Measures in the Dagona Waterfowl Sanctuary. MSc Thesis Submitted to the Department of Geography, University of Maiduguri

Carty P. and Lee E. (1995). In Shadow of the First World: The Environment as Seen from the Developing Nations. Review Press, A McGrath Book, Chicago, pp. 20-21

Crump A. (1991). Dictionary of Environment and Development: People, Places, Ideas and Organizations. Earthscan, London, pp. 8-9

Ezealor A.U. (2002). Hadejia-Nguru wetlands critical sites for biodiversity conservation in Nigeria, Nigerian Conservation Foundation, Lagos, pp. 66-68

Gisilambe A.M. (1998). Environmental education: by whom and for whom. Paper Presentation, Department of Geography, University of Maiduguri, Maiduguri, Nigeria

Idowu A.A., Popoola, O.C., Ipadeola A. and Nwekoyo V.E. (2020). Toxicity effect of Kigelia Africana aqeous extract on the haematology and histopathology of juvenile Nile Tilapia. Agro-Science, 19 (1), 37-42

Ipinyolu J.K. (1999). Issues in conservation of fisheries resources on the wetland of Northern Nigeria. Proc. $26^{\text {th }}$ Annual Conf. Forestry Association of Nigeria, held in Maiduguri, Borno State, 19th-23rd April, 1999
IUCN (1988). Hadejia-Nguru Wetlands Conservation Project (HNWCP), pp. 2-4. The Mission for International Union for the Conservation of Nature (IUCN)

Manu S.A. (2000). Effects of Habitat Fragmentation on the Distribution of Forest Birds in South Western Nigeria with particular Reference to the Ibadan Malimbes and other Malimbes. $\mathrm{PhD}$ Thesis, University of Oxford, p. 205

Mbanyiman S.E. (1990). Draft management plan for Dagona Waterfowl Sanctuary Borno State Nigeria. RSPB, No. 2, p. 7

Ramsar Convention Bureau (2000). Background papers on wetland values and function. Gland, Switzerland: Ramsar Convention Bureau. Accessed: http://www.ramsar.org/info/values, May 2019

Ringim A.S., Magige F.J. and Jasson R.M. (2017). A comparative study of species diversity of migrant birds between protected and unprotected areas of the Hadejia-Nguru Wetlands, Nigeria. Tanzanian Journal of Science, 4 (1), 2-5

Rowley J. and Winter M. (1998). Sustainable Livelihood in the Hadeija-Nguru Wetlands: APRA Study of Dagona Community. A Report to the Hadejia-Nguru Wetlands Conservation Project,,p. 22

Stopfords P.E.G. (1999). Bulatura oasis: A fragile ecosystem under threat. In: Nigeria Parks. The Magazine of the Nigerian National Parks

Wakirwa B. (1999). The Wetland Sector of Chad Basin National Parks. The Magazine of Nigeria National Parks May 1999, pp. 2-4

Weins J.A. (1997). The Ecology of Bird Communities: Foundations and Patterns. Cambridge University Press, Cambridge, 1: 539 